УДК 159.9.07

doi: $10.15330 / p s .10 .1 .29-36$

Олена Завгородня

Інститут психології імені Г. С. Костюка НАПН України

zolen1958@gmail.com

\title{
РОЗРОБКА ІНТЕГРАТИВНИХ СТРАТЕГІЙ У ПСИХОЛОГІЇ: ЗВЕРНЕННЯ ДО ТВОРЧОЇ СПАДЩИНИ Г. О. БАЛЛА
}

Окреслено сучасну пізнавальну ситуачію та методологічні проблеми психології. 3 огляду на ситуачію в науці показано, щзо сформульована й розвинута Г. О. Баллом раціогуманістична орієнтація в методології людинознавства має значний евристичний потенціал щзодо розробки інтегративних стратегій у психології. Пошук шляхів забезпечення інтеграції психологічного знання, опрацювання варіантів відповідних технологій учений вважав нагальним науковим завданням. Г. О. Балл проаналізував труднощі інтеграції, зокрема зумовлені поліваріантністю пізнання предмету психологічного дослідження; роллю суб 'єктивних преферениій дослідника; наявністю суб 'єктних якостей у досліджуваних; необхідністю узгодження результатів застосування методів різного ступеня об'єктивності. В контексті творчих напрацювань вченого, зокрема ідей, які ним були висловлені, проте не набули достатнього розвитку в його прачях, нами запропоновано інтегративно-екзистениійний підхід, спрямований на розробку інтегративних стратегій пізнання, насамперед особистості. Зазначений підхід базується на загально-наукових приниипах иілісності, активності, розвитку та взаємодії. Засадничим для підходу є принцип раціогуманізму в його світоглядних та методологічних вимірах. Окреслено також суттєві для підходу приниипи «ученого незнання», потрійного моделювання досліджуваної реальності, неостаточності теорії, ї̈ інструментального призначення, доповнюваності теорій, гнучкості методологічного бачення, рефлексивної «лінзокритики», осмислення «присутності» автора теорії, врахування стану психічної реальності та ї̈ антиномічності, чутливості до потреб дослідницької практики. Запропоновано низку аналітичних процедур, які доповнюють і посилюють одна одну. Різнобічність процедур створює основу для 1) співставлення різних концептуальних підходів до конкретної досліджуваної проблеми, 2) створення ампліфікованих моделей. Методи інтегративно-екзистенційного підходу, спрямовані на певну проблему, відповідно розширені і технологічно конкретизовані, можуть бути дієвим інтегративним інструментом у пізнанні особистості.

Ключові слова: інтегративні стратегій, раціогуманістична орієнтація, духовно-екзистенційний вимір, особистість, інтегративно-екзистениійний підхід, аналітичні процедури.

Постановка проблеми. Сучасна пізнавальна ситуація може бути охарактеризована через такі тенденції: зростання когнітивної складності в різних сферах повсякденного життя, науки і культури; усвідомлення обмеженості механістичного світобачення; зростання між- та трансдисциплінарних досліджень; інтерес до маргінальних, менш опрацьованих в культурі тем; інтерес до латентних ліній пізнання, до різних інтелектуальних традицій; гуманітаризацію; розвиток гуманітарної методології; низку явищ, які отримали назву «turns» («повороти», «зсуви»); міждисциплінарної інтеграції знання, зростання ролі постнекласичного ідеалу раціональності, принципів мережі в організації знання, поліпарадигмальності тощо [10, 17 та ін.]. Зазначені тенденції в контексті людинознавства пов'язані з прагненням глибокого і цілісного осягнення людиною своєї природи та сутності, що виявляється, зокрема, в посиленні позицій не лише історико-культурних, а й екзистенційних тенденцій, а також у зростанні значущості діалогу, налаштованості на взаємодію та можливу інтеграцію різних напрямків та рівнів гуманітарних знань у смисловому полі психології. Актуальність дослідження визначається особливостями сучасної пізнавальної ситуації, що передбачає розробку нових загально-гуманітарних підходів до розуміння людини в динамічному сьогоденні, в умовах «плинної реальності» [5], а в контексті психології особистості - інтегративних стратегій її пізнання.

Мета статті - висвітлення можливостей розвитку творчих напрацювань Г. О. Балла в розробці стратегій інтегративно-экзистенційного підходу.

Серед ознак проблемності методологічної ситуації, що склалася в сучасній психології особистості, дослідники акцентують 1) розрив між теоретичними пошуками та психологічною практикою; 2) проблему синтезу, пошуку засад для інтеграції різноманітності психологічного знання про особистість, порушення спадкоємності пізнання, проблему 
наступності, поєднання здобутків минулого і сьогодення психології; 3) роздробленість психології особистості, що стає перепоною для ії подальшого розвитку та використання. Попри активне обговорення проблеми інтеграції психологічного знання, констатується брак наукових моделей іï стихійного та цілеспрямованого здійснення [14; 18 та ін.].

У цьому контексті значний інтерес становить розроблена Г. О. Баллом раціогуманістична світоглядна та методологічна орієнтація в людинознавстві.

Виклад основного матеріалу й обгрунтування результатів дослідження. Окреслимо зміст раціогуманістичної орієнтації, звертаючись до праць ученого [1-4; 13], а також спираючись на розвідки його наукової спадщини [9 та ін.]. Раціогуманістична орієнтація передбачає визнання інтелектуальної культури (і науки як ії головного осередку) одним 3 найважливіших здобутків людства та максимальне використання цього багатства у його гармонійній взаємодії з іншими складниками культури для розширення знань про людину та для їх гуманістично орієнтованого застосування у різних сферах соціального життя. Серед ознак раціогуманістичної орієнтації можна акцентувати, зокрема, такі: людинознавча, гуманістична, етична спрямованість, налаштованість на піднесення людини, розкриття іiї творчих можливостей (що є суголосним антропологічному повороту у новітній науці); орієнтація на гармонійний раціоналізм, який спирається на інтелектуальну культуру в її найширшому розумінні (а відтак передбачає діалогічну взаємодію логічно обгрунтованих та інтелектуально осягнутих позицій, розвиток потенціалу різних позицій через діалог); увага до ціннісного аспекту наукової діяльності; конструктивна ревізія трансдисциплінарних категорій із категорією раціональності включно; орієнтація на забезпечення адекватності, змістовності, логічної чіткості, ясності моделей (зокрема системних описів) досліджуваних процесів з урахуванням їхньої складності; побудова відповідного поняттєвого інструментарію. За Г. О. Баллом, гармонійний інтелект людини не зводиться до відомих під назвою розсудку стандартизованих цивілізаційних варіантів, що легко піддаються формалізації, технологізації, автоматизації, а постає налаштованим на якнайповніше охоплення світу із доланням часових, просторових і змістових обмежень, спорідненим із давно відомим поняттям мудрості. Г. О. Балл зауважує: « $Є$ дві стратегії подолання труднощів, що виникають: одна - вдосконалення пізнавального розуму, друга - «перехід від розуму, що пізнає, до розуму взаємопорозуміння». Я, як правило, керуюся першою стратегією, але, визнаючи значущість другої, намагаюся зробити свій скромний внесок у їхній діалог» [1, с. 15].

Вчений доклав значних зусиль до впорядкування категорійно-термінологічного апарату психології. Одним з провідних аспектів цієї роботи було уточнення статусу низки трансдисциплінарних категорій (культура, гармонія, особистість, розум та ін.). Щодо багатьох із цих категорій Балл вважав доцільним узагальнювальний підхід - якнайширше трактування, порівняно з розрізнювальним підходом. Зокрема, щодо категорії особистості Балл обгрунтовував цей підхід так: «Ціннісним засадам гуманістично налаштованої психології відповідає якнайширше трактування поняття особистості (з одночасним виокремленням різних типів особистості, стадій ії становлення та рівнів досягнутого розвитку); 3 цих позицій, люди не діляться на тих, хто є особистістю, і тих, хто не є нею, шлях до особистісного зростання (з урахуванням індивідуальних особливостей і водночас з орієнтацією на особистісний ідеал, яскраво репрезентований у житті й діяльності багатьох видатних людей) визнається принципово відкритим для кожної людини, а надання допомоги у рухові цим шляхом - чи не головним обов'язком психолога» [3, с. 32].

Г. О. Балл запропонував інтегративно-особистісний підхід до розуміння психічних феноменів. Інтегративний - оскільки підкреслював, що розрізненість психологічного знання стає перепоною його розвитку. Вчений виокремлював труднощі інтеграції, зокрема зумовлені поліваріантністю пізнання предмету психологічного дослідження; роллю суб'єктивних преференцій дослідника; наявністю суб'єктних якостей у тих, кого досліджують; необхідністю узгодження результатів застосування методів різного ступеня об'єктивності. 
Особистісний - позаяк категорія особистості наразі висувається на перший план. Г. О. Балл, говорячи про духовний вимір особистості, писав, що він «не обов'язково втілюється в релігійну віру, проте присутній всюди, де людина керується смислами» [8, c. 270]. Учений відзначав важливість пізнання зазначеного духовного виміру, а психологічні концепції, які обмежуються соціальним та біологічним в розумінні психіки, вважав збідненими [8].

У контексті ідей Балла, які ним були висловлені, проте не набули достатнього розвитку (напр., про значущість духовного виміру особистості) нами було запропоновано інтегративно-екзистенційний підхід. Підхід налаштований на пошук інтегративних стратегій у пізнанні психічної реальності, а підкреслення духовно-екзистенційного аспекту пов'язано з прагненням глибокого і цілісного бачення психічної реальності, уникнення різних форм редукціонізму в ії трактуванні. В першу чергу, це стосується особистості [11; $12 ; 13]$.

Зазначений підхід базується на загально-наукових принципах цілісності, активності, розвитку та взаємодії. Ці принципи обрані як найбільш універсальні, такі, що сформувалися в різних політичних просторах, пройшли перевірку часом. Також важливими для нас $\epsilon$ принципи «ученого незнання», потрійного моделювання досліджуваної реальності, спіралі розуміння, осмисленої суб'єктності дослідника, прийняття антиномічності досліджуваної реальності та врахування різних її станів (застиглих, стійких, плинних, «летючих»), чутливості до потреб дослідницької практики (зокрема, явних та латентних течій інтеграції), неостаточності теорії, iï інструментального призначення, якнайширшого визначення об'єкта дослідження, рефлексивної «лінзокритики», гнучкості, транссистемності. Засадничим для нашого підходу є принцип раціогуманізму в його світоглядних та методологічних вимірах [1; 4].

Згідно з принципами изілісності, активності, розвитку та взаємодї розвиток сфери психології ми розглядаємо як її еволюційно спрямовані якісні зміни - зростання диференційованості та інтегрованості, досягнення більшої внутрішньої узгодженості та цілісності через осягнення суб'єктами сфери психології іiі сенсу, екзистенційного призначення, через активну взаємодію зазначених суб'єктів, спрямовану на подолання перешкод на шляху втілення осягнутого сенсу, посилення культуротворчої функції, іiї гуманізувального впливу, що, зокрема, передбачає інтеграційні зусилля.

Інтеграція (лат. integer - цілий, integratio - відновлення, відбудова, заповнення, доповнення) означає об'єднання в ціле, в єдність будь-яких елементів, відновлення будь-якої єдності; в широкому розумінні означає стан пов'язаності окремих диференційованих частин і функцій системи, організму в ціле, а також процес, що призводить до такого стану [6]. В контексті психології інтеграція означає активність суб'єктів цієї сфери, орієнтовану на їі цілісність, через знаходження медіаторів-посередників між розрізненими частинами, інтеграторів-об'єднувальників психологічного знання, і ширше - всієї сфери психології, включно з практикою, визначення спільних професійно-ціннісних орієнтирів. Будь-яка інтеграція, особливо цілеспрямована, пов'язана 3 активністю суб'єктів сфери психології, а також з їх взаємодією. Взаємодія зазначених суб'єктів може різною мірою сприяти комунікаційним та інтеграційним процесам у психології (налаштованість на співробітництво, орієнтація на загальнолюдські цінності, дотримання етичних засад), може також мати гальмівний вплив (перевага стратегій егоцентричного або групоцентричного суперництва, уникання або імітація співробітництва, ігнорування етичних засад тощо). Цілеспрямована інтеграція пов'язана 3 налаштуванням на сполучення і комунікацію всього цінного, накопиченого психологією, попри суперечності, об'єднання елементів (різних ідей, підходів, методів, технологій) в мережу 3 достатнім діапазоном свободи, координацію їх функцій залежно від проблеми, гнучке налаштування до завдань психологічної роботи (зокрема, на проблему дослідження або надання допомоги). Без інтеграційних зусиль не можна подолати роздробленість психологічного знання, розщеплення психо- 
логії на академічну і практичну, недостатню іï ефективність і відповідне розчарування, падіння престижу тощо.

Принципи ученого незнання та потрійного моделювання досліджуваної реальності. Принцип «ученого незнання» невіддільний від глибокого пізнання психічної реальності, зокрема, коли мова йде про духовно-екзистенційні джерела особистості. 3 ним пов'язаний принцип потрійного моделювання досліджуваної реальності. На основі принципу потрійного конструювання (моделювання) досліджуваної реальності ми виокремлюємо: 1) сферу проясненого, ясного бачення (мережа видимих та пояснюваних фактів), 2) сферу проблемного, мінливого або тьмяного бачення (мережа частково видимих, але недостатньо пояснюваних фактів), 3) сферу потенційного знання (вченого незнання) невидимого, невідомого, але передбачуваного.

Принцип неостаточності теорії полягає в її проникливості для нових ідей, нових даних, переструктурування. Принцип інструментального призначення тієї чи іншої концепції полягає у визначенні діапазону придатності та дослідницьких переваг певної концепції, підходу; перепрочитанні давніх концепцій в контексті сучасної ситуації; принцип інструментального призначення та принцип доповнюваності сприяють гнучкій різноракурсності бачення у процесі дослідження, практичності в роботі з фактами і, відповідно, кращому результату.

Принципи гнучкості та рефлексивної «лінзокритики» методологічного бачення полягає у рефлексії багатовимірності, багаторівневості та плинності психічної реальності, рефлексії взаємин між суб'єктом та об'єктом дослідження, суб'єктивності дослідника і суб' єктності досліджуваного (надання голосу об'єкту дослідження), аналізі обмеженості окремих позицій і способів методологічного бачення, виявленні їх соціально-психологічних, когнітивних та мотиваційних чинників (зокрема психологічних захистів), запобігає абсолютизації та ригідності дослідницьких настановлень, сприяє гнучкому використанню методологічних інструментів. Принцип рефлексивного опрацювання суб'єктивносmi дослідника (або «присутності» автора теорії, «не-алібі-в-бутті», за М. М. Бахтіним, суб'єкта психологічної сфери) полягає в необхідності рефлексії переживань, прагнень, ціннісних пріоритетів дослідника, простеженні зв'язків та спадкоємності різних близьких досліднику ідей, певного зрізу наукової культури, виявленні особливостей його наукового пошуку, його діалогічного простору, його проекцій, особливостей «вживання» в об'єкт дослідження.

Принцип транссистемності психічної реальності полягає в тому, що хоча метафора системи (чи мережі, чи навіть мережі систем різного рівня) не може охопити цю надскладну реальність в усіх іiі витоках, виявах та перетвореннях, зазначений метафоричний конструкт 3 напрацьованими на його основі аналітичними процедурами може мати достатньо плідне, продуктивне застосування (в різних формах системного підходу) в пізнанні та репрезентації людської психіки (попри іï транссистемну глибинну, нескінченну й неосяжну сутність та понадсистемний надлишок). Такі поняття, як цілісність, система, мережа, інтеграція тісно пов'язані між собою між собою, проте їх трактування не усталене і може бути предметом дискусій. Однією з проблем сучасної психології є непорозуміння в науковій спільноті, де частина дослідників спирається на конструкт системи (як на базовий), а частина більш адекватним вважає звернення до конструкту мережі. Прихильники мережного підходу асоціюють систему з певним порядком, а мережу зі своєрідним плідним хаосом, що породжує лад (порядок), пов'язують «мережу» 3 різноманітностю і пластичностю, а «систему» - 3 ригідністю, відзначають переваги мережного підходу - асиметричність, лабільність, гнучкість, чутливість до ситуації [7; 10]. Відзначимо (уникаючи дискусії щодо первинності і всеохопності обговорюваних конструктів), що гнучкість передбачає використання різних методологічних інструментів (в тому числі і напрацювань системного підходу). В інструментальному сенсі система (за Г. О. Баллом, широко трактована «без зведення до типів систем, недостатньо адекватних для багатьох психологічних застосувань») виступає як модель досліджуваного складного об'єкту 3 
відповідним виокремленням основних компонентів, між якими зафіксовані певні відношення; сукупність відношень характеризує структуру системи. Дослідник зосереджує у компонентах і структурі такої моделі свої уявлення про найсуттєвіше в об'єкті, в тому числі уявлення, отримані в ході його гуманітарно орієнтованого пізнання, значною мірою базованого на культурних традиціях, спонтанних спостереженнях та інтуїтивних узагальненнях [15].

Модель має підлаштовуватися під досліджувану реальність (як карта під репрезентовану нею територію), відображати найсуттєвіше, зокрема і її стан (затверділий чи плинний, «речовий» чи «атмосферний» тощо); i, власне, цим може визначатись іiі подібність до системи чи мережі.

Принщип прийняття антиномічності, необхідний у пізнанні надскладних реальностей, полягає у толерантності до суперечностей і невизначеності, ситуативному переструктуруванні пізнаваного поля відповідно до дослідницького завдання, ампліфікації та розширення діапазону медіаторів (інтелектуальний стиль, спосіб розмірковування тощо), зокрема діалогу як інструментів узгодження суперечностей.

Принции чутливості до потреб дослідницької практики полягає в униканні пізнавально-вольової сліпоти, деструктивного волюнтаризму у постановці інтеграційних завдань, у врахуванні внутрішніх потреб розвитку науки, явних та латентних інтегративних процесів, напрямків, течій; методологічного узагальнення стихійно сформованих реалій, екологічності пошуку.

Окреслимо методи інтегративно-екзистенційного підходу як конкретні інструменти дослідження актуальних психологічних проблем, що можуть бути використані в контексті фасилітації інтеграційних процесів у психології. Мова йде про особливим чином спрямовані аналітичні процедури та моделювання.

Запропоновано до апробації такі аналітичні процедури - системно-поліконцептуальний аналіз; транзитивний аналіз; поліфокусований рефлексивний аналіз, а також порівняльне поліконцептуальне моделювання.

Системно-поліконцептуальний аналіз полягає у визначенні діапазону придатності та дослідницьких переваг тієї чи іншої концепції (підходу), перепрочитанні давніх концепцій в контексті сучасної ситуації та конкретної проблеми; поєднанні та гнучкому використанні пізнавально-інструментальних можливостей різних концепцій щодо конкретної проблеми для розв'язання таких питань (з позиції підходу а, підходу b, .. підходу n):

- які метафоричні конструкти найкраще репрезентують досліджувану реальність;

- які факти (або мережа фактів) акцентуються в ній;

- які іï особливі властивості (атрибутивний аналіз);

- які сфери чи аспекти можна виокремити;

- які компоненти її складають;

- у чому полягають функції та дисфункції досліджуваної реальності;

- як компоненти поєднані в одне ціле (структурний аналіз);

- якими є генетичні аспекти досліджуваної реальності, висвітлення іiї історії розвитку (генетичний аналіз).

Транзитивний аналіз - гнучкий аналіз досліджуваної реальності в контексті їі станів - стійких («твердих»), плинних, «летючих».

Поліфокусований рефлексивний аналіз досліджуваної реальності у просторі їі пізнання полягає в різнорівневій рефлексії, зокрема суб'єктивності дослідницької позиції, виявлення ii переваг і недоліків, ролі психологічних захистів суб'єкта дослідження (дефензивно-психологічний аналіз), культурального контексту тощо.

Порівняльне поліконцептуальне моделювання - створення та співставлення кількох моделей досліджуваної реальності зі спиранням на різні підходи до її пізнання. Ми виходимо з такого трактування моделювання. Модель - об'єкт-замінник, який за певних умов може замінювати об'єкт-оригінал, відтворюючи ті властивості та характеристики, що цікавлять дослідника. Відтворення може здійснюватися в предметній (макет, пристрій), 
знаковій (графік, схема, програма, теорія) та образно-символічній (метафора, художній образ) та змішаних формах.

Модель - будь-яка система, що несе інформацію, яка може бути використана, про іншу/модельовану/ систему. Модельне відношення є тернарним, тобто пов'язує три системи: модель, активну систему (зокрема суб'єкта) та модельовану систему [1]. Модель має відповідати проблемі, бути практичною, гнучкою, придатною в роботі з фактами. Вона має гіпотетичний характер, відображає варіативність спроб вивчення реальності, прогнозування іï змін (активності, розвитку, згасання), може стати його оригінальним поясненням, інструментом знаходження нових властивостей, осередком як визнаних, так і нових дискусійних ідей. Моделі в одних випадках можуть бути термінологічно витримані, побудовані переважно на основі логічного підходу, вирізнятися впорядкованістю та завершеністю, а в інших - можуть бути побудовані переважно на основі інтуїтивного підходу, вчування та емпатії, мати вербально-образну та образно-символічну форму[16].

На основі принципів «ученого незнання» та потрійного конструювання моделі досліджуваної реальності ми виокремлюємо різні за ясністю сфери бачення. Застосування логічних конструктів є доцільним переважно щодо сфери ясного бачення (мережа видимих та пояснюваних фактів), а застосування метафорично-гіпотетичних конструктів може бути продуктивним щодо другої і третьої сфер, особливо в зоні «мінливої і недостатньої видимості».

Різні методичні стратегії в практиці перетинаються, поєднуються, доповнюють i посилюють одна одну. Така різнобічність процедур аналізу і синтезу створює основу для 1) співставлення підходів до, зокрема проблем психології особистості, 2) створення ампліфікованих моделей в процесі їх розв'язання.

Висновки і перспективи подальших досліджень. Творча спадщина Г. О. Балла має значний потенціал з огляду на сучасні виклики психології, роздробленість психологічного знання, актуальність пошуку шляхів інтеграції. В контексті творчих напрацювань вченого, ідей, які ним були висловлені, проте не набули достатнього розвитку в його працях, нами запропоновано інтегративно-екзистенційний підхід. Окреслено принципи і методи інтегративно-екзистенційного підходу. Запропоновано методичні інструменти, які, будучи розширені і технологічно конкретизовані стосовно актуальних проблем психології особистості, можуть сприяти їх новому баченню та розв'язанню у спільному просторі різних традицій, теорій, дослідницьких підходів.

1. Балл, Г. А. (2006). Психология в рацииогуманистической перспективе: избранные работыл. К.: Основа.

2. Балл, Г. О. (2008). Орієнтири сучасного гуманізму (в суспільній, освітній, психологічній сферах). Житомир: «Волинь» ПП «Рута».

3. Балл, Г. О. (2009). Інтегративно-особистісний підхід у психології: впорядкування основних понять. Психологія і суспільство, 4, 25-53.

4. Балл, Г. О. (2017). Раиіогуманістична орієнтайія в методології людинознавства: наукове видання. К.: Видавництво ПП «СКД».

5. Бауман, 3., Донскіс, Л. (2017). Плинне зло. Життя без альтернатив. Київ: Дух і літера.

6. Большой энциклопедический словарь (2016). Взято 3: https://www.vedu.ru/bigencdic/

7. Василькова, В. В. (2012) Сети в социальном познании: от метафоры к метатеории. Журнал социологии и соииальной антропологии, 15, 5, 11-24.

8. Гуманістична психологія: Антологія (2005). Т. 2. Психологія і духовність. Р. Трач і Г. Балл (упорядк.). К.: Пульсари.

9. Гуманний розум: збірник статей (присвячено пам'яті Георгія Олексійовича Балла) (2017). О. В. Завгородня, В. Л. Зливков (ред.); С. О. Лукомська, О. В. Федан (уклад.). К.: Педагогічна думка. Взято 3 http://lib.iitta.gov.ua/706694.

10. Гусельцева, М. С. (2015). Культурно-аналитический подход $к$ изучению эволючии психологического знания. (Дис...докт. психол. наук). Психологический институт РАО, Москва.

11. Завгородня, О. В. (2012). Особистість: інтегративно-екзистенційна трактовка. Психологія $i$ особистість, 1, 39-53. 
12. Завгородняя, Е. В. (2014). Личность: интегративно-экзистенциильный подход. Saarbrucken, Germany: LAP Lambert Academic publishing.

13. Інтегративно-особистісний підхід у психологічній науи̧і та практиці: монографія (2012). Г. О. Балл (ред). Кіровоград: Імекс-ЛТД,

14. Мазилов, В. А. (2003). Научная психология: тернистый путь к интеграции. Труды ярославского методологического семинара. Методология психологии. Ярославль: ЯГУ. Т.1, 136-138.

15. Системність психологічного знання на сучасному етапі його розвитку: монографія (2017).

О. В. Завгородня (ред.). Київ: Видавничий Дім «Слово». Взято з http://lib.iitta.gov.ua

16. Старовойтенко, Е. Б. (2007). Культурная психология личности: монография. М.: Академический проект; Гаудеамус.

17. Юревич, А. В. (2001). Методологический либерализм в психологии. Вопросы психологии, 5, 318.

18. Healy, P. (2012). Toward an integrative, pluralistic psychology: On the hermeneutico-dialogical conditions of the possibility for overcoming fragmentation. New Ideas in Psychology, 30, 271-280.

\section{REFERENCES}

1. Ball, G. A. (2006). Psykholohyia v ratsyohumanystycheskoi perspektyve: izbrannye raboty [Psychology in the ratiohumanistik perspective: selected works]. Kyiv: Osnova. (rus.).

2. Ball, G. O. (2008). Oriientyry suchasnoho humanizmu (v suspilnii, osvitnii, psykholhichnii sferakh). [Landmarks of modern humanism (in social, educational, psychological spheres)]. Zhytomyr: «Volyn» PP «Ruta». (ukr).

3. Ball, G. O. (2009). Intehratyvno-osobystisnyi pidkhid u psykholohii: vporiadkuvannia osnovnykh poniat [An integrative-personal approach in psychology: ordering basic concepts]. Psykholohiia i suspilstvo [Psychology and Society], 4, 25-53. (ukr).

4. Ball, G. O. (2017). Ratsiohumanistychna oriientatsiia v metodolohii liudynoznavstva [The Humanistic Orientation in the Methodology of Human Studies] Kyiv: PE «SKD". (ukr.).

5. Bauman, Z., Donskis, L. (2017). Plynne zlo. Zhyttia bez alternatyv [Flowing evil. Life without alternatives]. Kyiv: «Dukh i litera». (ukr).

6. Bolshoy entsiklopedicheskiy slovar (2016). [A large encyclopedic dictionary] Retrieved from https://www.vedu.ru/bigencdic/ (rus.).

7. Vasilkova, V. V. (2012). Seti v sotsialnom poznanii: ot metaforyi k metateorii [Networks in social cognition: from metaphor to metatheory]. Zhurnal sotsiologii $i$ sotsialnoy antropologii [Journal of Sociology and Social Anthropology], 5, 11-24. (rus).

8. Humanistychna psykholohiia: Antolohiia. (2005) [Humanistic Psychology: Anthology.] Vol. 2. Psychology and spirituality [Psychology and spirituality]. R. Trach and G. Ball (red.). Kyiv: Pulsary. (ukr.).

9. Humannyi rozum (prysviacheno pam'iati Heorhiia Oleksiiovycha Balla) [The humane mind (dedicated to the memory of Georgiy Ball)]. O. V. Zavhorodnia, V. L. Zlyvkov (red.). Kyiv: Ped. dumka. Retrieved from 3 http://lib.iitta.gov.ua/706694 (ukr).

10. Guseltseva, M. S. (2015). Kulturno-analiticheskiy podhod k izucheniyu evolyutsii psihologicheskogo znaniya [A cultural and analytical approach to the study of the evolution of psychological knowledge] Dissert. for... doctor. of psychol. sciences. Psikhologicheskiy institut RAO. Moskwa. (rus).

11. Zavhorodnia, O. V. (2012). Osobystist: intehratyvno-ekzystentsiina traktovka [Personality: an integrative-existential interpretation]. Psykholohiia i osobystist. [Psychology and personality]. 1, 39-53. (ukr).

12.Zavhorodniaia, E. V. (2014). Lychnost: intehratyvno-ekzystentsyalnbil podkhod [Personality: an integrative-existential approach]. Saarbrucken: LAP Lambert Academic publishing. (rus.).

13. Intehratyvno-osobystisnyi pidkhid u psykholohichnii nautsi ta praktytsi : monohrafiia (2012). [An integrative-personal approach in psychological science and practice: a monograph]. G. O. Ball (red.). Kirovograd: Imex-LTD. (ukr).

14. Mazylov, V. A. (2003). Nauchnaia psykholohyia: ternystыi put k intehratsyy [Scientific psychology: a thorny path to integration] (2003). Trudy yaroslavskoho metodolohycheskoho seminara. Metodolohyia psikhologii. [Proceedings of the Yaroslavl Methodological Seminar. Methodology of psychology]. Yaroslavl: YGY. T. 1, 136138. (rus.).

15. Systemnist psyhologichnoho znannia na suchasnomu etapi yogo rozvytku (2017). [Systematic psychological knowledge at the present stage of its development O. V. Zavgorodnya (red.). Kyiv: Vydavnychyi Dim «Slovo». Retrieved from http://lib.iitta.gov.ua. (ukr.).

16. Starovoytenko, E. B. (2007). Kulturnaya psihologiya lichnosti: monografiya [Cultural psychology of personality: monograph]. Moskwa: Akademicheskiy proekt; Gaudeamus. (rus.).

17. Yurevich, A. V. (2001). Metodologicheskiy liberalizm v psihologii [Methodological liberalism in psychology]. Voprosy psychologii [Psychology issues], 5, 3-18. (rus.).

18. Healy, P. (2012). Toward an integrative, pluralistic psychology: On the hermeneutico-dialogical conditions of the possibility for overcoming fragmentation. New Ideas in Psychology, 30, 271-280. 


\section{Olena Zavhorodnya \\ DEVELOPMENT OF INTEGRATIVE STRATEGIES IN PSYCHOLOGY: THE APPEAL TO THE CREATIVE HERITAGE OF GEORGY BALL}

The modern cognitive situation and methodological problems of psychology are outlined. In view of the above, it is shown that formulated and developed by Georgy Ball ratiohumanistic orientation of the methodology of human studies has considerable heuristic potential in the development of integrative strategies in psychology. Finding ways to ensure the integration of psychological knowledge, working out variants of relevant technologies scientist considered an urgent scientific task. He analyzed the difficulties of integration, in particular due to the multivariate knowledge of the subject of psychological research; the role of the subjective preferences of the researcher; the presence of subjective qualities in those who are being investigated; the need to reconcile the results of the application of methods of varying degrees of objectivity. In the context of the creative scientific achievements of Georgy Ball, in particular, the ideas that he expressed, but did not get enough development in his works, we proposed an integrative-existential approach, aimed at developing integrative cognition strategies, first of all, cognition of personality. This approach is based on general scientific principles of integrity, activity, development, interaction. Fundamental for our approach is the ratiohumanistic principle in its worldview and methodological dimensions. Are also outlined principles that are important to the approach (principles of «scientific ignorance», triple modeling of the investigated reality, incompleteness of theory, its instrumental purpose, complementarity of theories, flexibility of methodological vision, comprehension of the subjectivity of the author of the theory, consideration of the state of mental reality and its antinomy, reflexive criticism of researchers «lenses», sensitivity to the needs of the research practice. A number of analytical procedures are proposed that complement and reinforce each other. The diversity of procedures creates the basis for 1) comparing different conceptual approaches to a particular problem under study, 2) creating amplified models. This methods aimed at a specific problem, appropriately expanded and technologically specified, can be effective integrative instrument of personality cognition.

Keywords: integrative strategies, ratio-humanistic methodological orientation, personality, spiritualexistential dimension, existential-integrative approach, analytical procedures. 